\title{
Assessing Students' Speaking Skills at 2nd Semester Students of English Study Program IAIN Curup
}

\author{
Desfitranita \\ IAIN Curup \\ desfitranita@gmail.com
}

\author{
Bayu Senjahari \\ IAIN Curup \\ senjahari@gmail.com
}

\begin{abstract}
Speaking skill in English language learning is sometimes difficult for learners. Some students in second semester in IAIN Curup at English study program experienced errors in daily communication. This research tried to disclose what errors that the students did, to what extent the errors occurred. Qualitative approach was considered appropriate in this research because it did not try to generalize the findings but to deepen the case. Observation and open-ended Interview were applied to gather the data. As the instruments, field notes and voice recorder were utilized. The result shows that the students made errors in the four categories namely error in the using of be + adjectives, misplace be 'present time' and 'past time, missing verbs and error in applying preposition. Errors occurred in the circumstances of choosing sentence verbs time signal and the lack of awareness in placing 'be' for a sentence.
\end{abstract}

Keywords: Speaking errors, grammar, sentence construction 


\section{INTRODUCTION}

Improving speaking skills is one of the aims of English language learners. This skill tends to be the primary motivation in language learning. It is truism that English language learners learn English because they desire to talk to native speakers of English. However, some learners might find that it is a problematic because unlike others, speaking requires at least good pronunciation, grammatical accuracy, appropriate words choice as well as fluency. Language is about meaning, communication has relation with effort to across messages. Thus, to perform good speaking ability, language learners are suggested to attain the required components in speaking.

Moreover, Brown (2001) said that students speaking performance in the classroom should be achieved six kinds of oral production that are (1) imitative that focusing on specific characteristic of language, (2) intensive, that is higher than imitative where it is require the students to practice some language aspects, (3) responsive, the students is expected to respond for short conversation and replay to teacher or students-initiated question or comment, (4) transactional or dialog for exchange specific information as the wider of responsive, (5) interpersonal or dialog for maintaining social relationship purpose, (6) extensive for intermediate or advance level for the purpose or monologues, like summaries and oral report. By this standard of achievement, teacher can apply the variety of speaking activity in order to create speaking task properly.

It is fact that some language learners make errors spontaneously. This is common things to occur and many teachers advise that students should learn from errors. Yet, continuous and consistent errors should not be acceptable because it appears to become habit in the future. Moreover, some researches suggest that language-learning habit may determine the overall output quality. Thus, students could minimize the chance of making errors by providing correct input in language learning.

In addition, errors in speaking look more perceptible than other skills in language. It shows how good someone in running communication. Performing good pronunciation and using appropriate words choice are only some aspects that depict the whole speaking performance. Grammatical errors such as the using of 'be', adjectives, preposition, verbs and tenses of time are noticeable. These errors affect meaning in conversation and eventually the performance of speaking ability. 
This paper tried to asses some learners of English language speaking skills. In particular, it examined errors in speaking of those students in the State Islamic University (IAIN) Curup at second semester. Errors by definition, some grammatical forms, tenses, word choices etc. Throughout this study, it is expected that students will be aware of their errors and other studies that concern about improving speaking skill should follow. In regard to this, this study was directed to answer the following questions: (1). What errors do the students experience in speaking English? (2). To what circumstances do the students present the errors in speaking English?

\section{THEORITICAL FRAMEWORK}

\section{A. A concise view of Grammar}

Grammar is a system of rules and structure of language and it has a function to help the readers to recognize words order and word form to use. For most of EFL learners, the term of grammar is not a novel product and they know absolutely grammar as a language formula that construct the composition of words, phrases and clauses into variety of sentences. Therefore, by understanding grammar, learners believe that they will have the ability to write and speak in English correctly as well as they will have an understanding on how to compose words into sentence to be meaningful language.

Morover, Kumar (2013) stated that grammar is the study of words and the ways words work together; an invisible force that guides us as we put words together into sentences. Any person who communicates using a particular language, consciously or unconsciously becomes aware of the grammar of that language. Then, according to Nordquist (2018) grammar is the systematic study and description of a language. It is also a set of rules and examples dealing with the syntax and word structures morphology. Syntax and morphology are the study of linguistics. Syntax studies about sentence construction while morphology is the study of word formation. An understanding of syntax and morphology can be a perfect beginner's tool to better English. As learner, you might have learned the following:

In addition, he also stated that grammar is a set of rules and examples dealing with the syntax and word structures (morphology) of language. Without grammar, language would not work because 
people could not communicate effectively. He added that the grammar of a language includes basic axioms such as the existence of tenses of verbs, articles and adjectives and their proper order, how questions are phrased, and more. To conclude, there are two essentially ways of thinking about grammar :

\begin{tabular}{l|l|l|}
\cline { 2 - 3 } & \multicolumn{2}{c|}{ Prescriptive } \\
\hline What is grammar? & $\begin{array}{l}\text { A collection of rules } \\
\text { that govern how people } \\
\text { use a language }\end{array}$ & $\begin{array}{l}\text { Observable patterns in } \\
\text { the ways people use a } \\
\text { language }\end{array}$ \\
\hline $\begin{array}{l}\text { Where does grammar } \\
\text { come from? }\end{array}$ & Rule makers & $\begin{array}{l}\text { Communities } \\
\text { language users }\end{array}$ \\
\hline Grammar is ... & What I say it is & What we make it \\
\hline
\end{tabular}

\section{Part of speech}

Although some EFL learners have never been introduced specifically with the term of part of speech defines, some literatures seem to agree that part of speech is a category of words that have similar grammatical properties and functions. Commonly, there are eight parts of speech listed that are noun, verb, adjective, adverb, preposition, conjunction, and interjection. The meaning of each part, example and function with briefly discussed below:

\begin{tabular}{l|l|l|l|}
\hline $\begin{array}{l}\text { Part of } \\
\text { Speech }\end{array}$ & Function & $\begin{array}{c}\text { Examp } \\
\text { le Words }\end{array}$ & $\begin{array}{l}\text { Example } \\
\text { Sentences }\end{array}$ \\
\hline Verb & action or state & $\begin{array}{l}\text { to) be, have, } \\
\text { do, like, work, } \\
\text { sing, can, must }\end{array}$ & $\begin{array}{l}\text { EnglishClub.com is a } \\
\text { web site. } \\
\text { I like EnglishClub.com. }\end{array}$ \\
\hline Noun & thing or person & $\begin{array}{l}\text { pen, dog, work, } \\
\text { music, town }\end{array}$ & $\begin{array}{l}\text { This is my dog. } \\
\text { He lives in mv house. }\end{array}$ \\
\hline Adjective & describes a noun & $\begin{array}{l}\text { a/an, the, some, } \\
\text { good, big, red, } \\
\text { well, }\end{array}$ & $\begin{array}{l}\text { have two dogs. } \\
\text { My dogs are big. }\end{array}$ \\
\hline $\begin{array}{l}\text { Adverb } \\
\text { adjective arverb }\end{array}$ & $\begin{array}{l}\text { quickly, } \\
\text { silently, well, } \\
\text { badly, very, } \\
\text { really }\end{array}$ & $\begin{array}{l}\text { My dog eats quickly. } \\
\text { When he is very } \\
\text { hungry, he eats really } \\
\text { quickly. }\end{array}$ \\
\hline
\end{tabular}




\begin{tabular}{l|l|l|l|}
\hline Pronoun & replaces a noun & $\begin{array}{l}\text { I, you, he, she, } \\
\text { some }\end{array}$ & $\begin{array}{l}\text { Tara is Indian. She is } \\
\text { beautiful. }\end{array}$ \\
\hline Preposition & $\begin{array}{l}\text { links a noun to } \\
\text { another word }\end{array}$ & $\begin{array}{l}\text { to, at, after, on, } \\
\text { but }\end{array}$ & $\begin{array}{l}\text { We went to school on } \\
\text { Monday. }\end{array}$ \\
\hline Conjunction & $\begin{array}{l}\text { Joins clauses or } \\
\text { sentences or } \\
\text { words }\end{array}$ & and, but, when & $\begin{array}{l}\text { I like dogs and I like } \\
\text { cats. I like cats and } \\
\text { dogs. } \\
\text { I like dogs but I don't } \\
\text { like cats. }\end{array}$ \\
\hline Interjection & $\begin{array}{l}\text { short } \\
\text { exclamation, } \\
\text { sometimes } \\
\text { inserted into a } \\
\text { sentence }\end{array}$ & oh!, ouch!, hi!, & $\begin{array}{l}\text { Ouch! That hurts! } \\
\text { Hi! How are you? } \\
\text { Well, I don't know. }\end{array}$ \\
\hline
\end{tabular}

\subsection{Noun}

Proper nouns are those that refer to a particular person, place, thing, or idea such as America, George Bush, Mr. Bean and December. Swick (2005) stated that noun could be proper and common. On the other hand, nouns that do not refer to the criteria mentioned namely common nouns. Land, girls, money, test are the example of common nouns. Noun can be used as the subject of the sentence or the word that is performing the action of the sentence. The subject could be from a proper and common noun and it can be in form of singular and plural noun.

\begin{tabular}{c|c|}
\hline Dora is my best friend & Proper Noun \\
\hline The boys like to play soccer & Common Noun \\
\hline Where is the school? & Singular \\
\hline
\end{tabular}

Noun can also be used as direct and indirect objects. The direct object is the noun that receive the action of verb. In the sentences Lina likes my brother the word Lina and my brother are nouns; Lina is as a subject of the sentence and my brother is direct object that has a function as noun. While, indirect object usually stands before the direct object in the sentence and it is the person to whom or for whom something is provided. For example, Mother gives Nathan 
five dollars. Nathan is as indirect object of the sentence and it is a noun.

\subsection{Verb}

A verb helps to connect nouns that describe an action or occurrence. It also directs our sentences along in a variety of ways. Moreover, Swick added that verbs are the words in a sentence that describe the action of a sentence or that introduce the condition or state of someone or something in a sentence. Without a verb, a sentence is meaningless for example, a sentence "he washes his car" would have odd meaning in "he his car". Thus, verb is essential in a sentence.

In English, verb is the only part of speech that has various forms or changed face. It defines the tense and the time happening. In general, there are six basic verb forms are used to create the entire tense system of English: base form, present, past, infinitive, present participle, and past participle. These forms are illustrated in the following chart:

\begin{tabular}{|c|c|c|}
\hline Verb Form & Reguler & Irreguler \\
\hline Base form & Walk & fly \\
\hline Present & walk/walk & fly/flies \\
\hline Past & Walked & flew \\
\hline Infinitive & to walk & to fly \\
\hline Present Participle & Walking & flying \\
\hline Past Participle & Walked & flown \\
\hline
\end{tabular}

Besides, there are also some other types of verbs called transitive verbs and intransitive verbs. Transitive verbs are those that can have direct object while intransitive verbs are not followed by a direct object and these verbs are sometimes followed by a prepositional phrase.

Transitive Verb

Arnold buys a newspaper 


\begin{tabular}{|l|l|}
\hline Intransitive Verb & The baby crawls on the floor \\
\hline
\end{tabular}

\subsection{Adjective}

Adjectives are words that describe nouns or pronouns. They may come before the word they describe; usually noun/ noun phrase. It can also be placed at the end of a sentence if they describe the subject of a sentence. It usually occurs after the auxiliary verb (is/am/are and was/were) and linking verbs (sound, seem, look and get) (Beare, 1999)

$$
\begin{array}{ll}
\text { Example: } & \text { That is a beautiful picture. } \\
& \text { He is a perfect man } \\
\text { Examples: } & \text { That picture was beautiful } \\
& \text { The lecture looks great }
\end{array}
$$

\subsection{Adverb}

Adverbs are words that modify everything but nouns and pronouns. They modify adjectives, verbs and other adverbs (Strauss, 2011). It is the only part of speech that can come from everywhere in a sentence. Adverbs can easily identify in a sentence because adverbs are often formed by adding suffix -ly to the corresponding adjectives quick-quickly, beautiful--beautifully, happy--happily, etc. however, not all adverbs are formed with -ly such as soon, well, then, there, fast, now have no regular corresponding adjectives forms. Early, fast, hard, late and kindly are both adverbs and adjectives. The examples below illustrate how adverbs can modify verbs, adjectives, and other adverbs:

Verbs Adjectives

\section{Adverbs}

$\begin{array}{lll}\begin{array}{l}\text { The man walked } \\ \text { slowly }\end{array} & \begin{array}{l}\text { He is completely perfect } \\ \text { man. }\end{array} & \begin{array}{l}\text { She ran very fast } \\ \text { She sighed rather }\end{array} \\ \begin{array}{l}\text { Anna writes } \\ \text { carelessly }\end{array} & \begin{array}{l}\text { It is an extremely } \\ \text { strange idea }\end{array} & \text { He sang too quietly } \\ \text { Dad drove home } & \begin{array}{l}\text { He was partially } \\ \text { dressed }\end{array} & \end{array}$

Similar to adjectives, adverbs also have certain forms for comparative and superlative degrees. Some adverbs will 
put -er ending for comparative and -est to indicate superlative such as; early --- earlier --- the earliest, fast --faster--- the fastest and in general adverbs require more for comparative and most for superlative like beautifully --- more beautifully --- the most beautifully, and some adverb are irregular forms, for example well --- better --- the best, bad --worse --- the worst.

\subsection{Pronoun}

Pronoun is the part of speech that substitutes for nouns or noun phrases and designates persons or things asked for, previously specified, or understood from the context. It is used to replace words that usually are names or things. The English personal pronouns are:

\begin{tabular}{lll} 
& Singular & Plural \\
\hline First Person & $\mathrm{I}$ & We \\
Second Person & You & You \\
Third Person & He, she, it & They
\end{tabular}

In similar to nouns that have a gender, pronouns also do. The subjects $I$, we, and you can be used by males or females. Subject $\mathrm{He}$ is for masculine, she for feminine and it for neuter. The plural form of the third person pronoun is always they; used for masculine, feminine, or neuter. The function of a pronoun in a sentence is to replace a noun with the same characteristics; singular or plural, the gender and the same used in the sentence (subject, direct object, or indirect object).

\subsection{Preposition}

Some students sometimes neglect preposition in English and misplace it. Preposition connects a certain word in a sentence to a noun or pronoun. Essberger (1997) stated that preposition can be used in two ways; in a literal way and idiomatic way. In the literal way preposition use as exactly it expected. In the sentence, The boy run up the hill, the preposition up means that the boy went to the direction up rather than down. While, in idiomatic use the preposition 
occurs in idiomatic expression; that is, the meaning this expression has nothing to do with the literal meaning of preposition itself. In the sentence, I call up my friend the word up has nothing to do with the direction up. To call up someone means to telephone someone.

There are many English preposition that should be remember, however, the common preposition (though errors often happen) that beginners should know is in, on, and at. Similar with other part of speech, preposition has rules as well. It usually occurs before noun or noun phrase. The following table explains more about it (Loos, 2004)

\begin{tabular}{|l|l|l|}
\hline \multicolumn{1}{|c|}{ At } & \multicolumn{1}{c|}{ in } & \multicolumn{1}{c|}{ on } \\
\hline Precise Time & $\begin{array}{c}\text { Months, Years, } \\
\text { Centuries and Long } \\
\text { Periods }\end{array}$ & Days and Dates \\
\hline at 3 o'clock & in May & on Sunday \\
\hline at 10.30am & in summer & on Tuesdays \\
\hline at noon & in the summer & on 6 March \\
\hline at dinnertime & in 1990 & on 25 Dec. 2010 \\
\hline at bedtime & in the 1990s & on Mother Day \\
\hline at sunrise & in the next century & $\begin{array}{l}\text { on Independence } \\
\text { Day }\end{array}$ \\
\hline at sunset & in the Ice Age & on my birthday \\
\hline $\begin{array}{l}\text { at } \\
\text { moment }\end{array}$ & in the past/future & on New Year's Eve \\
\hline
\end{tabular}

\subsection{Conjunction}

Conjunctions serve to link words, phrase and sentences and can be divided into coordinators or coordinating conjunction, correlative conjunction and subordinating conjunction (Swick, 2005).

a. Coordinating Conjunction is a word that connects words, phrases, or sentences together and when it joins together two sentences, the resulting sentence is called a 
compound sentence. There are seven coordinating conjunctions: for, and, nor, but, or, yet, and so. The coordinate conjunctions in the following examples are italicized:

- John got up and walk out

- Not Paul, but Bill failed his test

b. Correlative Conjunction is a type of conjunction that functions in a pair of words that working together to balance words, phrases, or clauses. The most commonly used are both...and, either...or, neither...nor, and not only...but also.

- Both Yoko and Marco have problems

- Either you work hard or you leave

c. Subordinating Conjunctions consist of a subject and a verb. These clauses usually cannot stand-alone. Depend clauses are preceded by subordinating conjunction and combine with independent Clause. An independent clause is essentially a clause that can exist by itself in a given sentence that means that it does not need any additional information to exist.

- Although he was tired, he continued to run

- After she arrived, Alberto was the first to greet her

\subsection{Interjection}

Interjection is used to express emotion. Although it is rarely heard by EFL learners, interjection occurs in most writing work particularly comics or novel. In daily speaking, sometime interjection is not detectable though it is important to add sense/ feeling of the speakers' mood. There are a lot of interjections in English, the following list is the commonly heard (Jenning, 2005):

\section{Tense}

Sometimes, tenses are identified as the most difficult thing to learn in English. Many studies have tried to discover the best way to teach English tenses by using media, drilling and exercising. Conventional teaching, my own experience as student, the teacher teaches tenses through demonstrating formula/ pattern following. However, few students are succeeded in understanding how the tenses are actually worked. They tend to use present tense to talk something about the past. 
Unlike other language study, English shows time of happening by signaling tense thus by changing the verbs form. Tense is a grammatical category, typically marked on the verb, that deictically refers to the time of the event or state denoted by the verb in relation to some other temporal reference point. Richards (1990) stated that In general, there are three types of tense: present, past and future.

Examples:

He washes the car

He washed the car

He will wash the car
(The time is at now/ at present or habitual)

(The time is in the past/ it already finished)

(The activity does not happen yet)

\section{Sentence Construction}

Sentence construction is to develop good sentence or meaningful sentence. A good sentence should at least contain a subject and predicate. According to Jennings, basic word order in English is subject ---predicate--- and object. To put it simple, see the following sentence:

\begin{tabular}{l|l|l|l|}
\hline \multicolumn{1}{c|}{ Sentence } & \multicolumn{3}{|c|}{ Pattern } \\
\cline { 2 - 4 } & Subject & Predicate & Object \\
\hline a. Jack like potatoes & Jack & likes & potatoes \\
\hline $\begin{array}{l}\text { b. Jimmy and Shaun are rich } \\
\text { students }\end{array}$ & $\begin{array}{l}\text { Jimmy and } \\
\text { Shaun }\end{array}$ & are & $\begin{array}{l}\text { rich } \\
\text { students }\end{array}$ \\
\hline \begin{tabular}{l} 
c. They always eat fruits \\
\hline
\end{tabular} & They & always eat & fruits \\
\hline
\end{tabular}

Word order is very important in English because there is very little "case marking" --- a subject and an object have the same form (except for pronouns). For example, the sentence "Jack likes May." does not have the same meaning as "May likes Jack." The Subject (the person who "likes") comes before the verb. The Object (the person who receives the action of the verb) comes after the verb. 
The question that follows for most beginners is how to identify which are subject, predicate and object. There is no simple answer for this question, however, a quick way to know is to see the verb of the sentence. Verb is the key to sentence construction where usually verb is between noun/noun phrase. It also indicates predicate in a sentence.

For example:

a. The expensive book is mine ("is" is an auxiliary verb so the word the expensive book and mine are the subject and object).

b. The blue sky and the bright star are my favorite views ('are' is an auxiliary verb so the word the blue sky and the bright star as the subject and the word 'my favorite view' is the object).

c. The beautiful student always go to the library ('go' is verb so the word 'the beautiful student is the subject and the word 'the library' is the object).

The above examples are shallow in sentence construction. In order to understand better, learners have to understand English syntax as well. Knowledge about phrase and clause is necessary. The following examples show the general patterns for sentence formations are as follow:

\begin{tabular}{|c|c|c|}
\hline & $=\mathrm{NP}+\mathrm{VP}$ & $\rightarrow$ the man + loves the queen \\
\hline & $=\mathrm{NP}+\mathrm{Adj} P$ & $\rightarrow$ the girl + is smart \\
\hline \multirow{3}{*}{$\mathrm{P}$} & \multirow[t]{3}{*}{$=$ Det $+N$} & $\rightarrow$ the + teacher \\
\hline & & $\rightarrow$ the + book \\
\hline & & $\rightarrow$ an + apple \\
\hline $\mathrm{P}$ & $=\mathrm{V}+\mathrm{NP}$ & $\rightarrow$ read + the book \\
\hline \multirow{4}{*}{$\operatorname{djP}$} & \multirow{4}{*}{$=A d j+N$} & $\rightarrow$ nice + Place \\
\hline & & yoce \\
\hline & & $\rightarrow$ smart + student \\
\hline & & $\rightarrow$ tall + man \\
\hline
\end{tabular}
Adjective Phrase

$$
\mathrm{N}=\text { Noun, } \mathrm{V}=\text { Verb, Adj }=\text { Adjectives }
$$


To create a good sentence, speakers have to conform, at least, the above pattern. Otherwise, the intended meaning will not be achieved. Learn how to combine and understand part of speech that will help to construct a good sentence.

\section{B. Common Errors in Speaking English for ESL Learners}

1. Grammatical Errors

Some literatures state that error is a condition when learners have not learnt something correctly and consistently fail to achieve what should be done. Richard (1990) also divided the errors into two categories namely inter-lingual error and intralingual error. Intra-lingual error is produced by the interference of the native language L1 by which the learner tends to use their linguistic knowledge of L1 on some Linguistic features in the target language. While, inter-lingual is an error occurring because of a particular misuse of target language. Likewise, Coder (1991) said that learners error arise because of the interference of native language and the specific strategies used L2 learners in the process of second language acquisition.

Moreover, Dulay (1982) classified the error into two taxonomies called linguistics taxonomy error and surface strategy taxonomy error. Linguistic taxonomy error is an error occurs due to the effect of particular linguistics constituent and language component such as phonology, syntax, morphology, semantic, and lexicon, discourse. Further, surface strategy taxonomy emphasize on the way of surface structure altered. The most common types of this error are omission error, addition error, misinformation error, and disordering error.

In addition, classification of intra-lingual error derives from Richards (1990), he constructs some errors into five different categories namely; (1). Error in the production group of verb, (2). Error in the distribution of verb group, (3). Miscellaneous error, (4) Error the use of preposition, (5). Error the use of articles and (5). Error in use of questions.

2. Errors in Function 
Communication activities involve surrounding which are called as contexts. These factors affect the whole meaning of the utterances. Context includes time, place, distance between speakers, topics and how the conversation gets along. Chris identifies some common errors in conversation that eventually disturbs meaning (McCharthy, 2009):

Example 1:

\begin{tabular}{|c|c|}
\hline Context: & At lunchtime asking a friend to go out for \\
\hline \multirow[t]{2}{*}{ Incorrect } & A: "Do you like to eat lunch with us \\
\hline & "Yeah, sure. Where do you go?" \\
\hline \multirow[t]{5}{*}{ Correct } & $\begin{array}{l}\text { A: "Would you like to eat lunch with us } \\
\text { today?" }\end{array}$ \\
\hline & Or \\
\hline & $\begin{array}{l}\text { "Do you want to eat lunch with us } \\
\text { today?" }\end{array}$ \\
\hline & (More informal) \\
\hline & B: "Yeah, sure. Where are you \\
\hline Explanation: & $\begin{array}{l}\text { In English, the present simple using 'do } \\
\text { you like to...' is not a request form. B's } \\
\text { response asking for more information } \\
\text { using the simple present sounds odd } \\
\text { because the speakers are talking about } \\
\text { 'right now.' Thus, the appropriate } \\
\text { question asking for more information } \\
\text { about the plan for lunch would be "Where } \\
\text { are you going/are you going to go?" } \\
\text { (Present continuous/future plan). }\end{array}$ \\
\hline
\end{tabular}

\section{RESEARCH METHODOLOGY}

\section{Approach to Research}

This research adopts the qualitative approach. As Gay (2000) defines 'qualitative research seeks to probe deeply into the research setting in order to obtain understandings about the way things are, why they are that way, and how the teachers in the context perceive them' (Johnson, 2004). It also involved collecting, 
arranging and interpreting non-numerical information (Yin, 2003). The data in this research was verbal responses that were taken from the interview. It focused on the natural setting of the teachers' individual contexts.

The research was a case study in a sense that only investigating a group of second semester students in IAIN Curup who were enrolled in Speaking II subject at English study program. Case study is "an empirical inquiry that investigates a contemporary phenomenon within its real-life context, especially when the boundaries between phenomenon and context are not clearly evident". The advantage of a case study is that it can gain in-depth data and more focus to small sample population. According to Neale (2006) "case study provides much more detailed information than what is available through other methods", because it focuses on single person or group with the same bounded system. Besides, it allows one to present data collected from multiple methods (i.e., surveys, interviews, document review, and observation) to provide the complete story. In addition, it permits a researcher to reveal the way a multiplicity of factors have interacted to produce the unique character of the entity that is the subject of the study (Thomas, 1998). Thus, case study is able to present detail data about particular subject where the uniqueness might occur.

The qualitative approach helped me gain in-depth understanding about the research questions. The case study revealed the phenomena on some students in second semester that made common errors in speaking English when they were interview about personal information and daily activities. The research showed that these errors probably are caused by the lack of grammar understanding, part of speech and sentence formation. Unlike other research approaches, the result of this research does not signify generalization. In turn, it spotted details on the Indonesian EFL teachers' perceptions and challenge in teaching EIL based on their own teaching contexts. Thus, it is convinced qualitative approach was suitable on this research.

\section{Research Design}

\subsection{Participant Selection}

This study was carried out in IAIN Curup in speaking II class. The participants were chosen through procedures as 
follow: First, all students at second semester were asked to prepare the interview for about 30 minutes. Second, each student was personally had an interview with the researcher. There were 112 students as the participants in this research, 20 males and 92 females. All of them were timed for approximately ten minutes interview in each session. Averagely the participants were 19 years old and passed speaking I subject in the first semester.

\subsection{Data Collection Techniques and Instruments}

The participants were asked to talk about personal information and daily activities for five minutes based on the chosen topics (Gammidge, 2004).

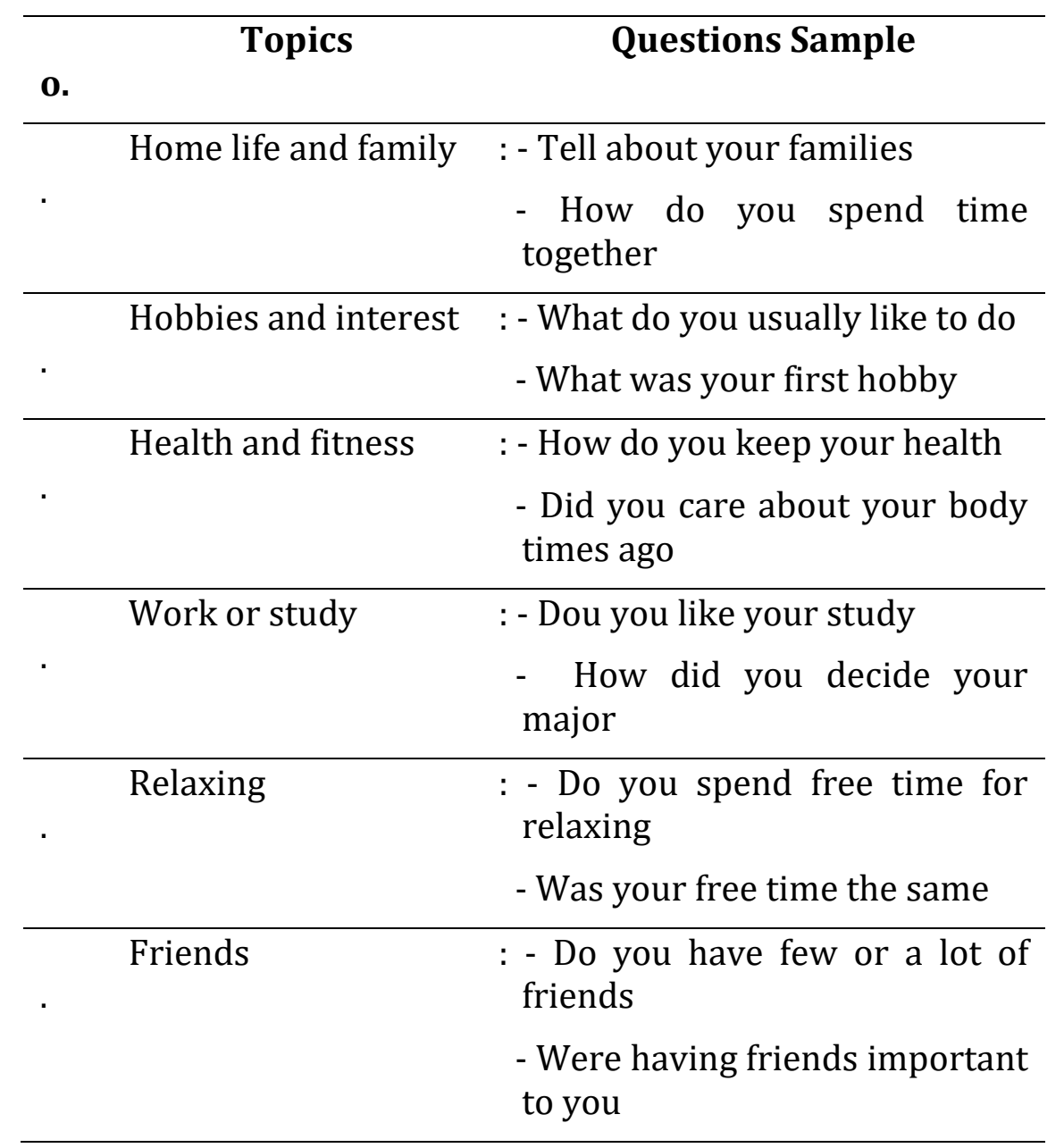


Spirituality
: - How do you maintain your mental health

- How important Prayer to you

Next, the researcher asked follow up questions to elaborate students talk. In each session, the researcher recorded while also took notes on students' errors for analysis. The study used partially structured interview technique. Gay states that partially structured interview enables the interviewer to randomly choose the order of the formulated questions. The interviewer may also add questions or modify them as deemed appropriate. Questions are open-ended and responses are recorded nearly verbatim. It found that some students lost ideas on what to talk about, after listening to the questions; they were back on track and easy to express ideas.

In addition, gay defines field notes as the instruments to collect data that is observer's record on what he has seen, heard, experienced and thought during observation. It contains descriptive and reflective aspects that provide description of the setting. Using field notes helped the researcher to write down students' errors in speaking English while they talked about their personal information and daily activities.

\subsection{Technique of Data Analysis}

The data first transcribed and simplified into the analysis as the researcher can identify the specific issues corresponding to the investigation. It also employed categorization or coding process (Cresswel, 2007). This process magnified the themes that occurred during the data analysis. In details, according to Tailor the following were some stages that the researcher employed in analyzing the data (Tailor, 2003):

\section{a). Get to know data}

The first thing was get to know the qualitative data. Actually, during the data collection, not all data were qualitative. Sometimes, the provided information did not add meaning at all. In this research, open-ended interview by using interview guide sometimes made the students 
answers came out from what the research needed. Even though it was qualitative data, sometimes it was not necessary to put in the analysis. In this research, the researcher certainly realize that some students spoke topics that out of the boundaries that was the research questions. However, the researcher strived to put the students responses kept on track. Sometimes, this caused difficulties due to limited time allocations.

\section{b). Focus the analysis}

The next step was focusing on the analysis to the research questions. Although qualitative research questions could change during the analysis, the key question will help where to get started. There are two common approaches to get the focus in analyzing. At first focus by topic, time or event and another way is focus by case, individual and group. The key words in this research were students' errors, students meaning and errors suggestion. Thus, the keywords are used to analyze starting points.

\section{c). Categorize information}

The information in the data then categorized in to components such as ideas, concepts, behaviors, interaction, and incidents that be organized in to coherent categories. The focus of the categories depended on the purpose of the research. There were two categories found in this research namely:

- Finding out students apparent errors

- Describing students point of view

d). Identify patterns and connection within and between categories

After making categories of the data, the next step was identifying patterns and connection between those categories to find themes. The categories were identified from smaller part; within two categories, among categories, and the relationship of all categories. There were four patterns in this research that is:

- The using of be+ adjectives

- Misplace be 'present time' and 'past time

- The missing verbs 
- Preposition problems

\section{e). Interpretation}

The last step was making interpretation of the themes. It should lead to researcher finding in his research as a result of data categorization. The result would be describing the purpose of the research questions. Sometimes, new finding which out of the research questions was found. Finally, the researcher tried to interpret in which area that the students need to improve in order to avoid errors in speaking. Then, to what starting points the students should move out to be better in English language learning eventually.

\section{FINDING AND DISCUSSION}

In this part, the finding stated some errors that occurred by the students. The data were classified based on the seven themes: home life and family, hobbies and interest, health and fitness, work or study, relaxing, friends and Spirituality. After decoding the transcript, it was found that there were 46 errors on students' utterances. Each error then analyzed to investigate the grammatical error types and situational errors. In the discussion section, the data were further explained and themed to disclose the research questions.

\section{A. Findings}

\begin{tabular}{|l|l|l|}
\hline o. & \multicolumn{1}{|c|}{ Themes } & \multicolumn{1}{c|}{ Utterances } \\
\hline & & - I born in 1992 \\
& & - She school \\
& Home life and family & - I am stay with my family \\
& & - He always hard work \\
& & - She have a married \\
& - I always together my mother \\
& & - She was married with her husband \\
\hline
\end{tabular}




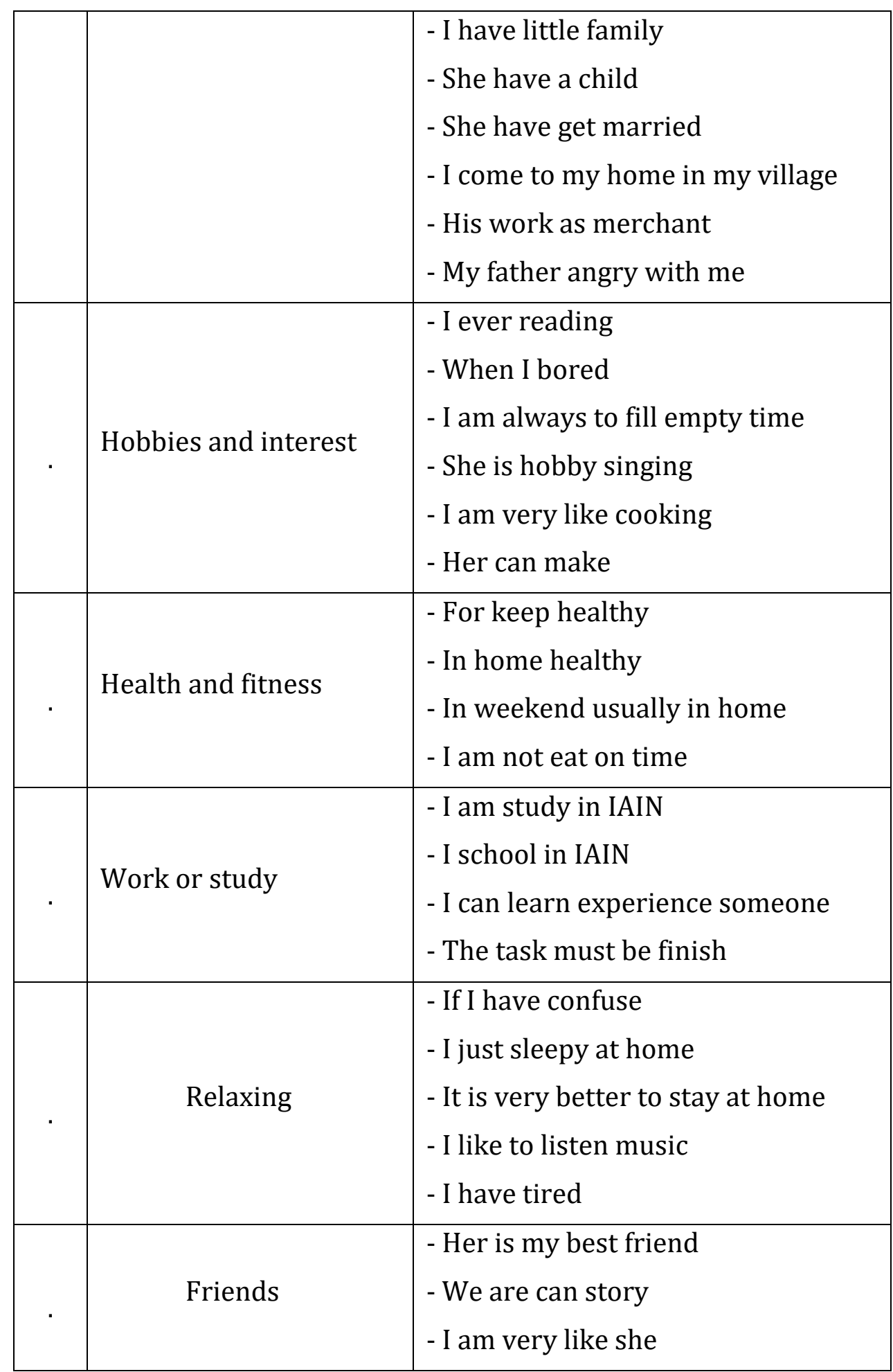




\begin{tabular}{|l|l|l|}
\hline & - We to can do \\
& - She is make me happy \\
& - I have much friend \\
& - I thing they are is kind \\
& - I not the same like other teenager \\
& - I followed organization \\
\hline \multirow{5}{*}{ Spirituality } & - I can feel peaceful \\
& - That's mean peace \\
& - I have Yoga \\
& - Pray on home \\
& - Give people good \\
\hline
\end{tabular}

\section{B. Discussion}

In this part, the writer restated the research questions and provided explanation based on two focuses. First, to find out what types of grammatical errors that the students committed in performing English speaking skills. Second, he elaborated contextual cue that lead to meaning preferences in conversation.

1. Students Grammatical Errors in Speaking English

1.1 Misplace be 'present time' and 'past time'

Tense in English language is very important. Unlike Bahasa where the time of happening is usually expressed by adding time signal only (adverb), English language needs certain change not only the addition of adverbs (every day, now, yesterday, tomorrow, a year ago) but also changing the verbs.

For examples:

$\begin{array}{lll}\text { go } & \rightarrow \text { went } & \begin{array}{l}\text { I went to school } \\ \text { yesterday }\end{array} \\ \text { want } & \rightarrow \text { wanted } & \begin{array}{l}\text { She wanted the ice cream } \\ \text { two days ago }\end{array}\end{array}$




$\begin{array}{lll}\text { clean } & \rightarrow \text { cleaned } & \begin{array}{l}\text { They cleaned the room } \\ \text { two hours }\end{array} \\ \text { See } & \rightarrow \text { saw } & \begin{array}{l}\text { He saw the man a } \\ \text { minute ago }\end{array} \\ \text { is/am/are } & \rightarrow \text { was/were } & \text { I was born ten years ago }\end{array}$

Therefore, by misplace the verbs and or the adverbs (as the time signal) will only compose meaningless sentences. The followings are the examples:

- I go to school yesterday (Everyday)

- She wanted (wants) the ice cream now

- They cleaned the room tomorrow-(Last week)

- He sees-(saw) the man a minute ago

- I am (was) born ten years ago

In speaking, speakers have to remember what the time of happening that he wants to express. If it is at present, speakers must make sure that the verbs (go, clean) and time signals are in present time (today, now, every morning etc). Moreover, If the time is in the past, the verbs should be in the past form (went, wanted) that are followed by past time signal (yesterday, 2 weeks ago). By mixing the verbs and adverbs, the sentence will be confusing for hearers.

1.2 The missing verbs

Verbs are the most important part of speech to create meaningful sentences. A verb adds meaning between nouns so that without verbs there is no clear relation/ meaning between nouns.

Some students might be confused about verbs in English. To identify verbs in a sentence is quite clear. A verb always occurs after noun/ pronoun or noun phrase.

For examples:

- They are teachers $\rightarrow$ 'are' is an auxiliary verb placed after 'they' as pronoun 
- John is crazy $\rightarrow$ 'is' is an auxiliary verb placed after 'John' as noun

- Mike and Michael go to the market $\rightarrow$ 'go' is a verb placed after 'mike and Michael' as Noun phrase

- The crazy man eats noodle $\rightarrow$ 'eat' is a verb placed after 'the crazy man' as noun phrase

1.3 Errors the use of preposition

Preposition is the last thing that speakers notify in speaking. Thus, it sometimes is neglected or forgotten. In fact, preposition is as important as other part of speech. The common prepositions that already learned for years are in/on/at/ that supposed never be errors anymore. However, some students sometimes misplace or even omit the preposition such as the following examples:

- I was born 1990

$\rightarrow$ missing 'in'

- I put the pen in the table

$\rightarrow$ misplace 'in' with 'on'

- He sticks the picture in the wall 'on'

- She lives on Merdeka Street 'at'

- $\quad$ The dog sleeps in night 'at'

$\rightarrow$ misplaced 'in' with

$\rightarrow$ misplaced 'on' with

$\rightarrow$ misplaced 'in' with

The good sentences should be:

- I was born in 1990

- I put the pen on the table

- He sticks the picture on the wall

- She lives at Merdeka Street

- The dog sleeps at night

1.4 The using of be+ adjectives

Adjective is usually related to one's feeling. For example, happy, sad, glad, curious, angry etc. It is easy to notify adjective in a sentence that typically adjective occurs before auxiliary verbs such as is/am/are or was/were.

Examples:

- She is angry

- They are happy 


\section{- I am curious}

Adjective can also be identified after particular words such as get/ like/ look/ sound/ seem and so on. After the words, adjectives must follow.

Examples: They look crazy

He seems sad

You sound lazy

However, some adjectives such as bored, confused, tired and interested are problematic. Students might misuse the function of these adjectives that they tend to apply the verbs form to express adjectives. Some errors occur such as:

- I am bore

- He is confusing

- She is tire

2. Functional Errors

- You are interesting

\begin{tabular}{|c|c|c|c|c|}
\hline o. & \multicolumn{2}{|r|}{ Utterances } & Context & Explanation \\
\hline & a. & $\begin{array}{l}\text { When I senior } \\
\text { high school }\end{array}$ & \multirow{2}{*}{$\begin{array}{l}\text { The student wanted } \\
\text { to express the time } \\
\text { in the past when he } \\
\text { was at high school }\end{array}$} & \multirow{2}{*}{$\begin{array}{l}\text { In English, to be is } \\
\text { very important to } \\
\text { signify the time } \\
\text { happening. It shows } \\
\text { clear points whether } \\
\text { the time is at } \\
\text { present, past or } \\
\text { future. }\end{array}$} \\
\hline & b. & $\begin{array}{l}\text { When I was at } \\
\text { senior high } \\
\text { school }\end{array}$ & & \\
\hline & . & $\begin{array}{l}\text { My father } \\
\text { working in } \\
\text { Medan }\end{array}$ & \multirow{2}{*}{$\begin{array}{l}\text { The student wanted } \\
\text { to say that his } \\
\text { father has a job out } \\
\text { town }\end{array}$} & \multirow{2}{*}{$\begin{array}{l}\text { Using verb+-ing is } \\
\text { always connected to } \\
\text { present happening } \\
\text { or on going process; } \\
\text { it never relates to } \\
\text { habitual. However, in } \\
\text { tenses, speakers are } \\
\text { rare to using 'present } \\
\text { continuous' to state } \\
\text { general truth such as } \\
\text { job and daily }\end{array}$} \\
\hline & & $\begin{array}{lr}\text { My } & \text { father } \\
\text { works } & \text { in } \\
\text { Medan } & \end{array}$ & & \\
\hline
\end{tabular}




\begin{tabular}{|c|c|c|c|}
\hline & & & $\begin{array}{l}\text { activities. Simple } \\
\text { present tense is } \\
\text { preferable }\end{array}$ \\
\hline . & $\begin{array}{l}\text { They are live } \\
\text { in Lebong }\end{array}$ & \multirow{2}{*}{$\begin{array}{l}\text { The student wanted } \\
\text { to say that he does } \\
\text { not stay with his } \\
\text { parents now and } \\
\text { told that his } \\
\text { parents live in } \\
\text { Lebong, his } \\
\text { hometown. }\end{array}$} & \multirow{2}{*}{$\begin{array}{l}\text { A meaningful } \\
\text { sentence must have a } \\
\text { verb. Usually, verb is } \\
\text { closely connected } \\
\text { with pronoun/ noun } \\
\text { The 'are' is auxiliary } \\
\text { verb that cannot be } \\
\text { followed by another } \\
\text { verb 'live'. }\end{array}$} \\
\hline & $\begin{array}{l}\text { They live in } \\
\text { Lebong } \\
\text { They are in } \\
\text { Lebong }\end{array}$ & & \\
\hline . & I study college & \multirow{2}{*}{$\begin{array}{l}\text { The student wanted } \\
\text { to express that he is } \\
\text { now actively as a } \\
\text { student at } \\
\text { University }\end{array}$} & \multirow{2}{*}{$\begin{array}{l}\text { Preposition is } \\
\text { sometimes ignored } \\
\text { in a sentence. } \\
\text { However, it is } \\
\text { equally important to } \\
\text { define meanings } \\
\text { between nouns. }\end{array}$} \\
\hline & I study college & & \\
\hline & $\begin{array}{l}\text { My hobby is } \\
\text { read novel }\end{array}$ & \multirow{2}{*}{$\begin{array}{l}\text { The student wanted } \\
\text { to say that he has a } \\
\text { hobby that relates } \\
\text { to reading novel. }\end{array}$} & \multirow{2}{*}{$\begin{array}{l}\text { Auxiliary verb 'is' is } \\
\text { usually followed by } \\
\text { verb+-ing or a noun } \\
\text { or an adjective. This } \\
\text { sentence shows an } \\
\text { activity as well that } \\
\text { 'present continuous' } \\
\text { should be the tense. }\end{array}$} \\
\hline & $\begin{array}{l}\text { My hobby is } \\
\text { reading novel }\end{array}$ & & \\
\hline & If I tired & \multirow{2}{*}{$\begin{array}{l}\text { The student wished } \\
\text { to say the condition } \\
\text { of his body; the } \\
\text { time when he gets } \\
\text { tired in his daily } \\
\text { activities. }\end{array}$} & \multirow{2}{*}{$\begin{array}{l}\text { The function of an } \\
\text { adjective is to state } \\
\text { one's feeling. The } \\
\text { construction should } \\
\text { always be preceded } \\
\text { by 'be' or 'auxiliary } \\
\text { verb' such as 'am, is, } \\
\text { was etc'. }\end{array}$} \\
\hline & If I am tired & & \\
\hline & $\begin{array}{l}\mathrm{He} \quad \text { always } \\
\text { watching TV }\end{array}$ & $\begin{array}{ll}\text { The } & \text { student } \\
\text { expressed } & \text { one of }\end{array}$ & $\begin{array}{lr}\text { To express } & \text { repeated } \\
\text { activities, } & \text { simple }\end{array}$ \\
\hline
\end{tabular}




\begin{tabular}{|c|c|c|c|}
\hline & $\begin{array}{l}\mathrm{He} \quad \text { always } \\
\text { watches TV }\end{array}$ & $\begin{array}{l}\text { his brother habits } \\
\text { that are watching } \\
\text { TV every night. }\end{array}$ & $\begin{array}{l}\text { present tense is } \\
\text { preferable. Present } \\
\text { continuous which is } \\
\text { usually contains } \\
\text { Verb+- ing is used to } \\
\text { express an activity } \\
\text { that is happening } \\
\text { now and not } \\
\text { repeated regularly. }\end{array}$ \\
\hline & $\begin{array}{l}\text { They are work } \\
\text { as farmer }\end{array}$ & \multirow{2}{*}{$\begin{array}{l}\text { The student wanted } \\
\text { to state his parents' } \\
\text { job as a farmer. }\end{array}$} & \multirow{2}{*}{$\begin{array}{l}\text { Problem in using } \\
\text { present tense } \\
\text { sometimes deals } \\
\text { with redundancy. } \\
\text { After using a verb or } \\
\text { auxiliary verb, a } \\
\text { noun or noun phrase } \\
\text { should follow. }\end{array}$} \\
\hline & $\begin{array}{l}\text { They are } \\
\text { farmers } \\
\text { They work as } \\
\text { farmers }\end{array}$ & & \\
\hline & $\begin{array}{l}\text { I interesting } \\
\text { with novel }\end{array}$ & \multirow{2}{*}{$\begin{array}{l}\text { The student wished } \\
\text { to say one of his } \\
\text { hobbies. He likes } \\
\text { novel and loves } \\
\text { reading it at all } \\
\text { time. }\end{array}$} & \multirow{2}{*}{$\begin{array}{l}\text { Two problems with } \\
\text { this sentence, first is } \\
\text { the missing of 'be' } \\
\text { prior to adjective, } \\
\text { second, the misuse of } \\
\text { preposition 'with'. } \\
\text { The adjective } \\
\text { 'interested' is } \\
\text { connected with } \\
\text { preposition 'in'. It is } \\
\text { also known as } \\
\text { colloquial language. }\end{array}$} \\
\hline & $\begin{array}{lr}\text { I } & \text { am } \\
\text { interested } & \text { in } \\
\text { novel } & \end{array}$ & & \\
\hline \multirow[t]{2}{*}{0} & $\begin{array}{ll}\text { Every } & \\
\text { morning, he } \\
\text { went } \\
\text { garden }\end{array}$ & \multirow{2}{*}{$\begin{array}{l}\text { The student wanted } \\
\text { to express his } \\
\text { father daily activity. } \\
\text { His father has a } \\
\text { garden and look } \\
\text { after the plants } \\
\text { every morning }\end{array}$} & \multirow{2}{*}{$\begin{array}{l}\text { All sentences that } \\
\text { express regular } \\
\text { activity usually apply } \\
\text { 'simple present' } \\
\text { tense. This sentence } \\
\text { has time manner } \\
\text { 'every morning' that } \\
\text { shows daily activity } \\
\text { so that the word } \\
\text { 'went' (past form of }\end{array}$} \\
\hline & $\begin{array}{l}\text { Every } \\
\text { morning, he } \\
\text { goes to garden }\end{array}$ & & \\
\hline
\end{tabular}




\begin{tabular}{|c|c|c|c|c|}
\hline & & & & $\begin{array}{l}\text { 'go') should be } \\
\text { replaced by the word } \\
\text { 'goes' }\end{array}$ \\
\hline \multirow[t]{2}{*}{1} & . & $\begin{array}{l}\text { I am born on } \\
1993\end{array}$ & \multirow{2}{*}{$\begin{array}{l}\text { The student wanted } \\
\text { to say the year } \\
\text { when he was born }\end{array}$} & \multirow{2}{*}{$\begin{array}{l}\text { The word 'born' } \\
\text { never connect with } \\
\text { be 'am' because it } \\
\text { happened in the } \\
\text { past; be 'was' is } \\
\text { better preference. } \\
\text { Preposition 'on' is } \\
\text { not constructed with } \\
\text { year manner; 'in' is } \\
\text { appropriate. }\end{array}$} \\
\hline & • & $\begin{array}{l}\text { I was } \\
\text { born in } 1993\end{array}$ & & \\
\hline \multirow[t]{2}{*}{2} & . & $\begin{array}{l}\text { I am not } \\
\text { understand }\end{array}$ & \multirow{2}{*}{$\begin{array}{lr}\text { The } & \text { student } \\
\text { showed } & \text { his } \\
\text { difficulty } & \text { in } \\
\text { understanding } \\
\text { particular situation } \\
\text { in his life. }\end{array}$} & \multirow{2}{*}{$\begin{array}{l}\text { The word' } \\
\text { understand' is a } \\
\text { verb, thus, to negate } \\
\text { the sentence, it } \\
\text { needs to be 'do/ } \\
\text { does' and not is/am } \\
\text { or are. Auxiliary verb } \\
\text { is followed by an } \\
\text { adjective or noun. }\end{array}$} \\
\hline & & $\begin{array}{l}\text { I do not } \\
\text { understand }\end{array}$ & & \\
\hline
\end{tabular}

Notes: $\mathrm{a}=$ Incorrect, $\mathrm{b}=$ Correct

It was found that situational errors that the students created were mostly about time signal. It seems that the students wanted to express their idea about past time, however, both present simple and continuous were often introduced instead of using past tense. In addition, the function of 'to be' and verb were also omitted; after noun phrase then directly came another noun phrase or adjectives. To sum up, the students' errors were as the results of first language interference that might have different sentence construction with English, thus, likely affected the way the students delivered the sentences. 


\section{CONCLUSION AND SUGGESTIONS}

Errors are not taboo in learning, particularly learning language. It always occurs in language learners. Based on the findings of this study, some students did errors in speaking. The possible causes of errors are: first, the students lack of knowledge in English language, particularly the sentence part of speech and how the rule of sentence construction. Second, the students have difficulties in applying tense in English. They seem to experience confusion how verbs work in English sentence construction. English sentence depends on verbs for signaling time of happening. Misplacing the incorrect verb forms will change the overall meaning.

To suggest, Speaking skill is the most complicated area in language learning. It needs a comprehensive understanding in grammar, syntax, semantics, morphology or pragmatics. Many have agreed that to be better in speaking skills, learners are advised not only to be fluent but also accurate in speaking. Further, in the coming research, it is suggested that researchers to investigate the use Arabic linguistics knowledge to contribute in English language learning, by providing fact that the students at IAIN Curup also study Arabic.

\section{REFERENCES}

Beare, Kenneth. (1999). How to Use Adjectives. New York Times Company: New York. Retrieved Aug, 3, 2012, from http://esl.about.com/od/grammarforbeginners/a/adjective use.h $\underline{\mathrm{tml}}$.

Brown, H. D. (2001). Teaching by principle: An interactive approach to language pedagogy (2nd ed.). San Francisco: Longman.

Corder, S.P. (1991) Error Analsysis and Interlanguage. Oxford: Oxford University Press.

Creswell, J. W. (2007). Qualitative Inquiry \& Research Design. Sage Publications, Inc: Thousand Oaks.

Dulay, H., Burt, M., \& Krashen, S. (1982). Language Two. Great Britain: Oxford University Press

Essberger, Josef. (1997). Preposition of time: at, in, on. Retrieved July, 27, 2012, from http://www.englishclub.com/grammar/prepositionsat-in-on-time.htm 
Gammidge, Mick. (2004). Speaking Extra. Cambridge University Press: Cambridge.

Gay, L. R and Peter, A. (2000). Educational Research: Competencies for Analysis and Application (6 ${ }^{\text {th }}$ ed.). Prentice-Hall: Merrill Publishing Company

Jenning, Sally. (2005). Basic English Sentence Structure. Retrieved Aug, 15, 2012, from http://www.speak-readwrite.com/grammar1.html

Johnson, B and Christensen, L. (2004). Educational Research: Quantitative, Qualitative and Mixed Approach. Boston: Pearson Education

Kumar, Pradeep Debata. (2013). The Importance of Grammar in English Language Teaching: A Reassessment. Language in India. Retrieved Mei, 12, 2019, from www.languageinindia.com ISSN 1930-2940 Vol. 13:5 May 2013

Loos, Eugene E. (2004). What is tense? Retrieved 12, Aug, 20012, from http://www.sil.org/linguistics/GlossaryOfLinguisticTerms/WhatI sTense.htm.

McCarthy, Chris. (2009). Common Errors in Speaking and Writing. Retrieved July, 13, 2012, from http://www.ecenglish.com/learnenglish/lessons/commonerrors-speaking-and-writing.

Neale, P., Shyam, T and Carolyn, B. (2006). Preparing a Case Study: A Guide for Designing and Conducting a Case Study for Evaluation Input. Pathfinder International. Retrieved June, 3, 2008, from http://www.pathfind.org/site/DocServer/m_e_tool_series_case_st udy.pdf? docID $=6302$.

Nordquist, Richard (2018) . Definitions, Examples, and Discussions of English Grammar. Retrieved may, 05, 2019, from https://www.thoughtco.com/what-is-grammar-1690909

Richards, J. C. (1990). Error Analysis: Perspectives on second language acquisition. Routledge. Tarigan, H. G. \& Tarigan, D

Straus, Jane. (2011). Adjectives and Adverbs. The Blue Book of Grammar and Punctuation. Retrieved Aug, 7, 2012, from http://www.grammarbook.com/grammar/adjAdv.asp 
70 | ENGLISH FRANCA, Vol. 3, No. 1, 2019

Swick, Ed. (2005). English Grammar for ESL Learners: Practice Makes Perfect. The McGraw-Hill Companies, Inc. USA

Tailor, E and Powel, M. R. (2003). Analyzing Qualitative Data. University of Wisconsin: Extension Cooperative Extension Madison, Wisconsin. Retrieved December, 25, 2005, from http://www. s142412519.onlinehome.us/uw/pdfs/G3658_12.PDF

Thomas, R M. (1998). Conducting Educational Research: A Comparative View. Bergin \& Garvey: London

Yin, R. K. (2003). Case Study Research: Design and Methods. (3rd ed.). Sage Publications, Inc: Thousand Oaks 